\title{
BEBAN KERJA DAN KONFLIK KERJA SEBAGAI PENJELAS TERJADINYA STRESS KERJA PELAUT
}

\author{
Renny Hermawati ${ }^{1 *}$, Suganjar ${ }^{2}$ \\ ${ }^{1}$ Universitas Maritim AMNI Semarang, JL. Soekarno Hatta No. 180 Semarang, Indonesia \\ 2. Balai Pendidikan dan Pelatihan Transportasi Laut, JL M Kahfi II No. 88 Cipedak, \\ Jagakarsa, Jakarta Selatan \\ *Corresponding Author. Email : rennyhermawati@unimar-amni.ac.id. HP: \\ 089655499760
}

\begin{abstract}
Abstrak
Pekerjaan sebagai seorang pelaut merupakan pekerjaan yang rentan dengan kebosanan. Durasi kontrak kerja yang relative panjang dengan beban kerja dan konflik pekerjaan yang tinggi, rentan terhadap kelelahan yang dapat memicu terjadinya stress kerja. Dari review yang dilakukan pada penelitian terdahulu menunjukkan bahwa beban kerja dan konflik kerja berpengaruh positif dan signifikan terhadap stress kerja di beberapa objek penelitian yang berbeda. Hal tersebut menjadikan indikasi bahwa diduga beban kerja dan konflik kerja akan berpengaruh terhadap stress kerja jika dilakukan study pada pelaut Indonesia. Pengujian pengujian terhadap model pengujian statistik yang dilakukan pada data penelitian, dilakukan dengan pendekatan uji regresi berganda. Hasil dari pengujian yang dilakukan menunjukkan bahwa stress kerja yang dialami oleh pekerja di atas kapal dipengaruhi oleh beban kerja dan konflik kerja, sehingga dalam temuan ini dapat diketahui bahwa apabila stress kerja yang dialami oleh para pelaut saat bekerja di atas kapal, maka hal tersebut disebabkan oleh munculnya peningkatan beban kerja serta konflik kerja bagi para pelaut Indonesia yang bekerja di atas kapal.
\end{abstract}

Kata Kunci: Beban kerja, konflik kerja, stress

\begin{abstract}
The job as a seamens is vulnerable to boredom. The relatively long duration of work contracts with workloads and high work conflicts, are prone to fatigue which can lead to work stress. From a review conducted in several previous studies showed, if workload and work conflict have a positive and significant effect on work stress in several different research objects. This makes an indication that the alleged workload and work conflict will affect work stress if a study is conducted on Indonesian seamens. The Tests carried out on statistical testing models conducted on research data, with the multiple regression test approach. The results of the tests showed that work stress experienced by seamen $s$ on board is affected by workloads and work conflicts. In this finding it can be seen that if the work stress experienced by seamens while working on board, then it is caused by the emergence of increased workloads as well as work conflicts for Indonesian seafarers who work on board.
\end{abstract}

Keywords: workload, work conflict, stress 


\section{PENDAHULUAN}

Pelaut adalah setiap orang yang mempunyai kualifikasi keahlian atau keterampilan sebagai awak kapal Peraturan Pemerintah Republik Indonesia Nomor 7 Tahun 2000 Tentang Kepelautan Presiden Republik Indonesia. Bidang pekerjaan seorang pelaut di atas kapal bervariatif tergantung dari jabatan dan departmentnya bekerja. Mengoperasikan mesin kapal, peralatan navigasi kapal, mengoperasikan mesin-mesin juga memastikan mesin dan perangkat kepal berfungsi secara efektif sepanjang perjalanan di laut (Fillhumaam, Nurcholis, \& Nurahaju, 2019). Dalam durasi kontrak kerja yang panjang, tugas tersebut cenderung meningkat terlebih apabila selalu melewati pelayaran yang panjang, sehingga akan menimbuklan tekanan atau stress. Stres yang terus menerus terjadi di atas kapal, akan menimbulkan respon kelelahan bagi seorang pelaut yang bekerja di atas kapal dalam durasi yang berkepanjangan.

Pelaut yang stres (mengalami tekanan) cenderung menganggap suatu pekerjaan bukanlah sesuatu yang penting bagi mereka sehingga tidak mampu menyelesaikan pekerjaannya sesuai dengan target yang telah ditetapkan. Akan tetapi tidak semua pelaut yang mengalami tekanan pekerjaan tidak mampu menyelesaikan pekerjaannya tepat waktu dan sesuai dengan target yang telah ditetapkan. Stres dapat mempengaruhi motivasi seseorang, baik secara positif maupun negatif. Stres kerja yang terjadi pada seorang pelaut tersebut, jika tidak segera diatasi dapat berdampak pada perilaku yang tidak diharapkan oleh organisasi di atas kapal.

\section{KAJIAN LITERATUR}

\section{Stress Kerja}

Stress kerja oleh Salleh, Bakar dan Keong (2008) dimaknai sebagai suatu tekanan, kekuatan atau suatu kecenderungan maupun suatu upaya mental yang dilakukan seseorang terhadap pekerjaanya. Menurut (Robbins, Judge, Odendaal, \& Roodt, 2016), terdapat tiga kategori gejala yang dimunculkan seorang yang mengalami stress kerja, yaitu gejala fisiologis, gejala psikologis, dan gejala perilaku. Gejala yang paling awal muncul ketika seorang karyawan mengalami stress kerja adalah gejala fisiologis yang berupa munculnya gangguan medis. Gangguan medis yang seringkali muncul pada gejala fisiologis adalah munculnya gangguan metabolisme tubuh, pernafasan dan detak jantung yang meningkat demikian juga tekanan darah, munculnya gangguan sakit kepala bahkan yang paling ekstrim adalah munculnya serangan jantung.

Upaya mental selanjutnya yang menunjukkan terjadinya stress kerja adalah adanya gangguan psikologis. Gangguan psikologis yang sering muncul adanya munculnya perasaan ketidakpuasan. Ketidakpuasan ini menjadi gejala yang paling jelas dan yang paling sederhana dari gangguan psikologis. Namun, tidak menutup kemungkinan munculnya gejala psikologis lainnya seperti munculnya kecemasan yang berlebihan, sering merasa tegang, individu menjadi mudah marah, lebih mudah bosan, dan senang untuk menunda-nunda pekerjaan. Pekerjaan yang memiliki banyak tuntutan terhadap karyawannya, aktifitas pekerjaan yang saling bertentangan atau mungkin juga tugas, tanggung jawab ataupun wewenang yang

Majalah Ilmiah Bahari Jogja 41 | http://jurnal.amy.ac.id/index.php/MIBJ/ 
tidak jelas menjadi factor pemicu yang mendorong terjadinya ketidakpuasan yang menjadi awal terjadinya stress kerja.

Gejala selanjutnya dari manifestasi stress kerja adalah gejala perilaku. Gejala perilaku lebih mudah diamati dibandingkan dua gejala sebelumnya karena terefleksi dari perilaku individu yang mengalami stress kerja. Gejala perilaku dari adanya stress kerja meliputi tingkat produktivitas yang cenderung mengalami penurunan, serta tingkat kemangkiran bahkan meningkatnya tingkat resign. Dalam dunia pelaut hal tersebut tentu sangat berbahaya, sebab akan memicutimbulnya berbagai perilaku negative, misalnya konsumsi makan, alkohol dan rokok yang berlebihan, tidur yang gelisah dan tidak berkualitas serta intonasi bicara yang cepat. Berbagai hal yang telah dijabarkan tersebut sekaligus juga dapat menjadi indikasi terjadinya stress kerja pada seorang pelaut.

\section{Beban Kerja}

Menpan (dalam Dhania, 2010), memberikan pemahaman beban kerja merupakan kumpulan atau lebih dari satu kegiatan yang semestinya dikerjakan oleh unit kerja tertentu dalam perusahaan atau oleh pemangku jabatan tertentu untuk suatu periode waktu tertentu. Sedangkan menurut Permendagri No. 12/2008, beban kerja dimaknai sebagai suatu ukuran pekerjaan yang harus ditanggung pada posisi atau unit tertentu dalam perusahaan yang melibatkan perkalian dari kuantitas pekerjaan dan ukuran waktu (Utomo, 2008). Oleh karena itu, beban kerja dapat dimaknai sebagai bentuk tanggung jawab tugas dan pekerjaan yang harus diselesaikan baik oleh individu maupun kelompok jabatan tertentu dalam situasi yang normal dan untuk periode tertentu. Sedangkan pendapat lain yang menyatakan pendapat bahwa tugas yang dituntut untuk dikerjakan oleh seorang individu menjadi tekanan pada beban kerja dijelaskan dalam buku Tarwaka Beban Kerja (workload). Menurut Hart \& Staveland dalam (dalam Tarwaka, 2011) bahwa: "Beban kerja merupakan suatu yang muncul dari interaksi antara tuntutan tugas-tugas lingkungan kerja dimana digunakan sebagai tempat kerja, keterampilan dan persepsi dari pekerja. Beban kerja kadang-kadang didefinsikan secara operasional pada faktor-faktor seperti tuntutan tugas atau upaya-upaya yang dilakukan untuk melakukan pekerjaan." Faktor-faktor yang mempengaruhi beban kerja menurut Utomo (2008) adalah sebagai berikut; (a) Banyaknya pekerjaan, (b) Target kerja, (c) Kebosanan, (d) Kelebihan beban, (e) Tekanan kerja.

\section{Konflik Kerja}

Menurut Malayu Hasibuan (2013), konflik adalah suatu persaingan kurang sehat berdasarkan ambisi dalam hal - hal seperti ketidakcocokan, ketidaksetujuan atau ketegangan baik intra individu maupun interentitas social seperti individu, kelompok ataupun organisasi. Anantan (2007), konflik adalah suatu kompetisi yang terjadi dalam suatu organisasi dapat terjadi karena adanya perbedaan pendapat mengenai tujuan perusahaan, antar bagian, antar unit kerja, para manajer yang bersaing dan berkonflik untuk memperebutkan posisi dan kekuasaan. Selain itu Anantan (2007) mengutarakan bahwa konflik merupakan suasana batin yang berisi kegelisahan dan pertentangan antara dua motif atau lebih mendorong seseorang untuk melakukan dua tau lebih kegiatan yang saling bertentangan. Bila 
tidak dikendalikan secara baik akan menimbulkan perpecahan di antara individu yang ada dalam perusahaan.

Handoko (2000) menyatakan bahwa konflik adalah ketidaksesuaian antara dua atau lebih anggota-anggota yang timbul karena adanya kenyataan bahwa mereka harus membagi sumber daya yang terbatas atau kegiatan-kegiatan kerja dan/karena kenyataan bahwa mereka mempunyai perbedaan status, tujuan, nilai, atau persepsi. Robbins et al., 2016 dalam Tika (2006) mendefinisikan konflik sebagai suatu proses yang mulai bila satu pihak merasakan bahwa ada pihak lain yang mempengaruhi secara negatif, hal itulah yang selalu diperhatian oleh pihak pertama. Bentuk konflik dalam batasan pengaruhnya terhadap perusahaan (Sanjaya,2010): (1) konflik fungsional, (2) konflik disfungsional, (3) konflik dan kinerja perusahaan. Gitosudarmo (2000) menjelaskan sebab-sebab terjadinya konflik yaitu: ketergantungan tugas, persaingan terhadap sumber-sumber, perbedaan tujuan dan prioritas, rintangan komunikasi, faktor birokrasi, dan sifat individu.

\section{Pengembangan Hipotesis}

\section{a. Pengaruh Beban Kerja terhadap Stress Kerja}

Serangkaian tanggung jawab akan dibebankan pada pelaut yang bekerja pada setiap kapal sesuai dengan job description dan jabatannya. Seringkali pekerjaan yang dilakukan tersebut melebihi apa yang sudah tertera dalam job descriptionnya yang kemudian direspon sebagai beban kerja. Beban kerja yang terus menerus yang dialami seorang pelaut tersebut akan menimbulkan stress kerja.

Moorhead, Griffin, (2010), menyatakan bahwa konsekuensi final dari struktur peran yang lemah adalah kelebihan beban kerja (peran) yang terjadi ketika ekspektasi untuk peran tersebut melampaui kemampuan individual. Hal tersebut mengandung makna apabila seorang Nakhoda atau pemimpin department diatas kapal memberikan beberapa tugas besar kepada seorang pelaut sekaligus sambil meningkatkan beban kerja regular pelaut tersebut, dimungkinkan akan mengalami beberapa kelebihan beban kerja.

Beban kerja yang bisa menyebabkan terjadinya stres kerja diantaranya adalah sistem pemberian tugas yang berlebihan, dan tekanan dan sikap pimpinan terhadap target kerja yang kurang adil dan tidak wajar. Hal-hal tersebut bisa menyebabkan terjadinya stres kerja pada seorang individu (Fathoni, 2009).

Tabel 1. Studi Terdahulu Beban Kerja terhadap Stres Kerja

\begin{tabular}{|c|c|c|c|}
\hline Sumber Penelitian & Variabel Penelitian & $\begin{array}{c}\text { Teknik } \\
\text { Analisis }\end{array}$ & Hasil Penelitian \\
\hline $\begin{array}{l}\text { Purbaningrat \& Ketut } \\
\text { (2015) }\end{array}$ & \begin{tabular}{l}
\multicolumn{2}{l}{ Variabel Bebas: } \\
$-\quad$ Beban kerja \\
Variabel Terikat: \\
$-\quad$ Stress kerja \\
$-\quad$ Kepuasan kerja
\end{tabular} & Regresi & $\begin{array}{l}\text { Beban kerja berpengaruh } \\
\text { signifikan positif } \\
\text { terhadap stress kerja }\end{array}$ \\
\hline $\begin{array}{l}\text { Kusuma Aster Andriani } \\
\text { (2014) }\end{array}$ & $\begin{array}{l}\text { Variabel Bebas: } \\
\text { - Beban kerja } \\
\text { Variabel Terikat: }\end{array}$ & Smart PLS & $\begin{array}{l}\text { Beban kerja berpengaruh } \\
\text { signifikan positif } \\
\text { terhadap stress kerja }\end{array}$ \\
\hline
\end{tabular}

Majalah Ilmiah Bahari Jogja 43 | http://jurnal.amy.ac.id/index.php/MIBJ/ 


\begin{tabular}{|c|c|c|c|}
\hline & $\begin{array}{ll}- & \text { Stress kerja } \\
- & \text { Kinerja }\end{array}$ & & \\
\hline Hatmawan (2015) & $\begin{array}{l}\text { Variabel Bebas: } \\
-\quad \text { Konflik kerja } \\
-\quad \text { Beban kerja } \\
-\quad \text { Lingkungan kerja } \\
\text { Variabel Terikat: } \\
-\quad \text { Stress kerja }\end{array}$ & Regresi & $\begin{array}{l}\text { Beban kerja berpengaruh } \\
\text { signifikan positif } \\
\text { terhadap stress kerja }\end{array}$ \\
\hline Rizky \& Afrianty (2018) & $\begin{array}{l}\text { Variabel Bebas: } \\
-\quad \text { Beban kerja } \\
\text { Variabel Terikat: } \\
\text { - } \quad \text { Work life balance } \\
\text { - } \quad \text { Stress kerja }\end{array}$ & Regresi & $\begin{array}{l}\text { Beban kerja } \\
\text { berpengaruh } \\
\text { signifikan positif } \\
\text { terhadap stress kerja }\end{array}$ \\
\hline $\begin{array}{l}\text { Zulmaidarleni et al., } \\
\text { (2019) }\end{array}$ & $\begin{array}{l}\text { Variabel Bebas: } \\
\text { - } \quad \text { Beban kerja } \\
\text { - } \quad \text { Lingkungan kerja } \\
\quad \text { fisik } \\
\text { Variabel Terikat: } \\
\text { Stress kerja }\end{array}$ & Regresi & $\begin{array}{ll}\text { - } & \text { Beban kerja } \\
\text { berpengaruh } \\
\text { signifikan positif } \\
\text { terhadap stress kerja }\end{array}$ \\
\hline
\end{tabular}

Sumber: Disarikan dari Berbagai Jurnal, 2020

\section{b. Pengaruh Konflik Kerja terhadap Stress Kerja}

Stres merupakan suatu kondisi ketegangan yang mempengaruhi emosi, proses berpikir dan kondisi seseorang. Hasilnya stress yang terlalu besar dapat mengancam kemampuan seseorang untuk menghadapi lingkungan, yang akhirnya mengganggu pelaksanaan tugas tugasnya (Handoko, 2012). Konflik di tempat kerja yang terlalu berlebihan terhadap seorang pelaut dapat menimbulkan stress yang berkepanjangan, yaitu kondisi atau keadaan yang tidak menyenangkan yang dihadapi oleh seorang pelaut baik secara fisik maupun mental. Stres di lingkungan kerja dapat terjadi pada setiap level menejemen mulai dari top manajemen sampai pada rating.

Tabel 2. Studi Terdahulu Konflik Kerja terhadap Stres Kerja

\begin{tabular}{|c|c|c|c|}
\hline Sumber Penelitian & Variabel Penelitian & $\begin{array}{c}\text { Teknik } \\
\text { Analisis }\end{array}$ & Hasil Penelitian \\
\hline Hatmawan (2015) & $\begin{array}{l}\text { Variabel Bebas: } \\
-\quad \text { Konflik kerja } \\
-\quad \text { Beban kerja } \\
-\quad \text { Lingkungan } \\
\text { kerja } \\
\text { Variabel Terikat: } \\
\text { Stress kerja }\end{array}$ & Regresi & 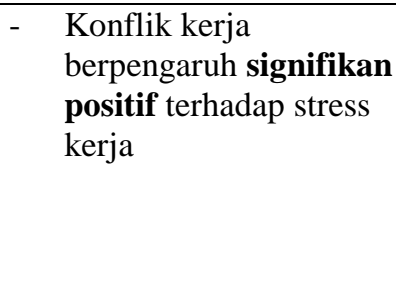 \\
\hline Anuari et al. (2017) & $\begin{array}{l}\text { Variabel Bebas: } \\
-\quad \text { Konflik kerja } \\
\text { Variabel Terikat: } \\
-\quad \text { Stress kerja } \\
-\quad \text { Motivasi kerja } \\
-\quad \text { Komitmen } \\
\quad \text { organisasional }\end{array}$ & Regresi & 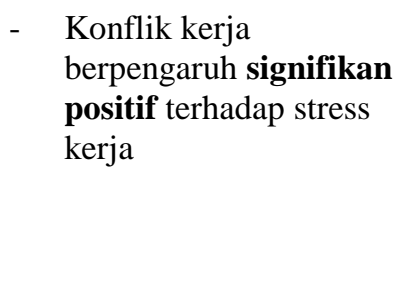 \\
\hline $\begin{array}{l}\text { Han \& Ketut Netra } \\
\text { (2014) }\end{array}$ & $\begin{array}{l}\text { Variabel Bebas: } \\
\text { - } \quad \text { Konflik kerja }\end{array}$ & SEM & $\begin{array}{l}\text { - } \quad \begin{array}{l}\text { Konflik kerja } \\
\text { berpengaruh signifikan }\end{array}\end{array}$ \\
\hline
\end{tabular}

Majalah Ilmiah Bahari Jogja 44 | http://jurnal.amy.ac.id/index.php/MIBJ/ 


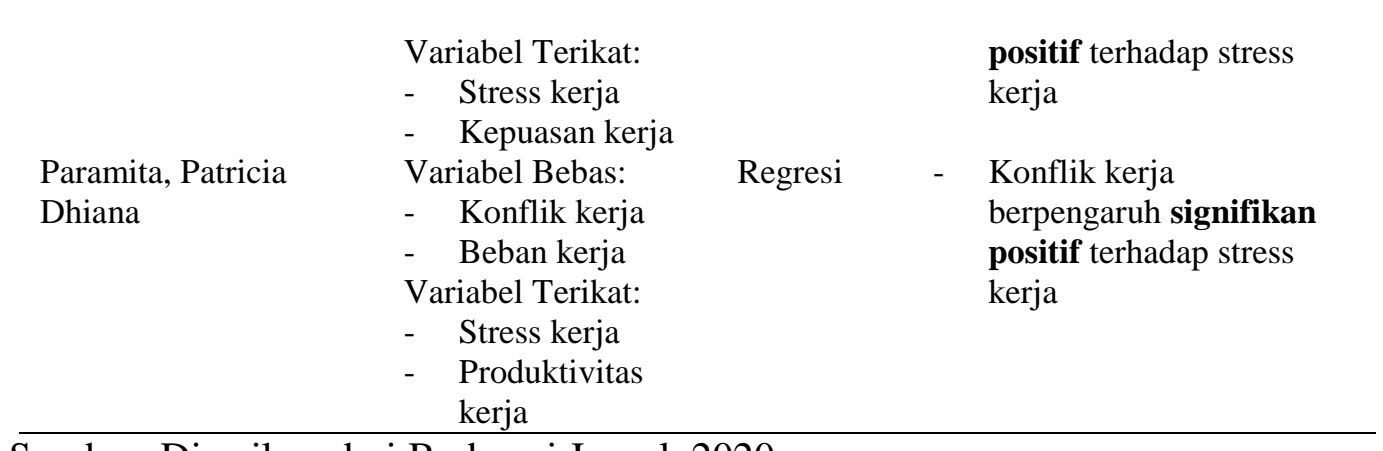

Sumber: Disarikan dari Berbagai Jurnal, 2020

\section{Model Empiris}

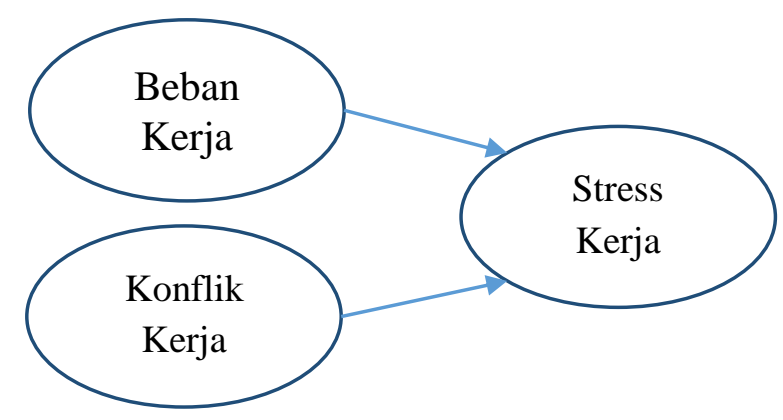

Gambar 1. Model Empiris Penelitian

\section{METODE PENELITIAN}

\section{Populasi dan Sampel}

Populasi dan sampel dalam studi ini merekrut para pelaut Indonesia yang bekerja di perusahaan Pelayaran Niaga dalam negeri dengan kontrak kerja minimal 6 bulan.

\section{Pengembangan Indikator}

Stres kerja pada pelaut diukur dengan menggunakan skala yang disusun penulis berdasarkan teori Braham (dalam (Hardjana, 1994) yaitu: (1). Fisik, yakni seorang pelaut mengalami gangguan pencernaan, radang usus, kulit gatal-gatal, punggung terasa sakit, urat-urat pada bahu dan leher terasa tegang, keringat berlebihan, berubah selera makan, tekanan darah tinggi atau serangan jantung, kehilangan energi. (2). Emosional, yakni seorang pelaut memiliki perasaan tidak nyaman, sehingga mudah tersinggung dan terlalu sensitif, merasa gelisah dan cemas.Suasana hatinya juga mudah berubah-ubah, sehingga ia merasa sedih yang berlebihan, mudah menangis dan depresi, gugup, agresif terhadap orang lain dan mudah bermusuhan serta gampang menyerang, dan kelesuan mental. (3). Intelektual, yakni seorang pelaut mengalami kekacauan pikiran sehingga sulit untuk berkonsentrasi, sukar mengambil keputusan, mudah lupa karena daya ingat menurun, suka melamun berlebihan, di penuhi satu pekerjaan saja. (4). Interpersonal, yakni seorang pelaut memiliki sifat acuh dan mendiamkan orang 
lain, kepercayaan pada orang lain yang menurun, dan mudah mengingkari janji pada orang lain.

Beban kerja diukur dengan menggunakan lima indicator yang meliputi: (1) banyaknya pekerjaan, (2) target pekerjaan, (3) kebosanan, (4) kelebihan beban kerja, dan (5) tekanan pekerjaan.

Konflik kerja diukur dengan menggunakan lima indikator berikut, yaitu (1) pertentangan antar individu atau kelompok, (2) perselisihan atau perbedaan persepsi antar individu atau kelompok, (3) terjadinya pertentangan antara norma atau nilai individu dengan norma atau nilai organisasi, (4) adanya sikap saling meniadakan, menghalangi, menang sendiri dalam keputusan dalam organisasi, (5) perdebatan atau perselisihan sebagai akibat munculnya kreativitas, inisiatif atau gagasan baru antara anggota organisasi.

\section{Pengumpulan Data}

Data penelitian dikumpulkan dengan menggunakan kuesioner yang terdiri dari item-item pernyataan tertutup. Responden akan memberikan jawaban pada skala $1-7$ yang menggambarkan kondisi yang dipersepsikan atas pernyataan yang diajukan

\section{Teknik Analisis}

Analisis data yang digunakan dalam studi ini menggunakan pendekatan Uji Regresi Berganda yang dijalankan dengan program SPSS(Astriawati, 2016).

\section{PEMBAHASAN}

Berdasarkan fenomena empiris dan teoritis yang dijustifikasi, studi ini dilakukan untuk menguji secara empiris pengaruh beban kerja dan konflik kerja terhadap stress kerja. Berikut ini diuraikan hasil pengujian statistik yang dilakukan pada data penelitian dengan pendekatan uji regresi berganda.

\section{Pengujian Model Penelitian}

Pengujian model penelitian dilakukan untuk menguji signifikansi fungsi bahwa terjadinya variasi pada stress kerja dapat dijelaskan oleh beban kerja dan konflik kerja. Pengujian model penelitian ini dilakukan dengan menguji signifikansi $\mathrm{F}$ hitung.

Tabel 3. Hasil Pengujian Model Penelitian

\begin{tabular}{lrrrrr}
\hline \multicolumn{5}{c}{ ANOVA $^{\mathbf{a}}$} \\
\hline Model & Sum of Squares & df & Mean Square & F & \multicolumn{1}{c}{ Sig. } \\
Regression & 3466,484 & 2 & 1733,242 & 69,307 &, $000^{\mathrm{b}}$ \\
Residual & 6352,061 & 254 & 25,008 & & \\
Total & 9818,545 & 256 & & & \\
a. Dependent Variable: Stress Kerja & & & & \\
b. Predictors: (Constant), Konflik Kerja, Beban Kerja \\
\hline
\end{tabular}

Sumber: Data Primer yang Diolah, 2020 
Pengujian kelayakan model dilakukan dengan menganalisis nilai signifikansi dari Uji $\mathrm{F}$ yaitu sebesar 0,000 yang kurang dari $\alpha(0,05)$. Hal ini menunjukkan bahwa variabel independen yang digunakan, yaitu beban kerja dan konflik kerja merupakan variabel yang tepat/layak untuk menjelaskan terjadinya variasi pada stress kerja.

\section{Analisis Koefisien Determinasi}

Analisis koefisien determinasi dilakukan untuk mengetahui kemampuan variabel penjelas, yaitu beban kerja dan konflik kerja dalam menjelaskan variasi yang terjadi pada stress kerja. Analisis koefisien determinasi ini dilakukan dengan menganalisis nilai Adjusted R Sqaure.

Tabel 4. Analisis Koefisien Determinasi

\begin{tabular}{|c|c|c|c|c|}
\hline \multicolumn{5}{|c|}{ Model Summary } \\
\hline Model & $\mathrm{R}$ & R Square & Adjusted R Square & $\begin{array}{c}\text { Std. Error of the } \\
\text { Estimate }\end{array}$ \\
\hline 1 &, $594^{\mathrm{a}}$ & ,353 &, 348 & 5,001 \\
\hline \multicolumn{5}{|c|}{ a. Predictors: (Constant), Konflik Kerja, Beban Kerja } \\
\hline
\end{tabular}

Sumber: Data Primer yang Diolah, 2020

Nilai Adjusted R Square pada penelitian ini adalah sebesar 0,348 atau sebesar $34,8 \%$. Nilai ini menunjukkan bahwa apabila terjadi variasi atau perubahan pada stress kerja maka 34,8\%-nya disebabkan oleh terjadinya perubahan pada beban kerja dan konflik kerja.

\section{Pengujian Hipotesis}

Pengujian terhadap kedua hipotesis yang diajukan dalam penelitian ini dilakukan dengan menggunakan Uji t dengan kriteria sebagai berikut :

a. Jika nilai signifikansi $<0,05$ maka dapat disimpulkan bahwa variabel independen terbukti secara statistik berpengaruh terhadap variabel dependen

b. Jika nilai signifikansi > 0,05 maka dapat disimpulkan bahwa variabel independen tidak terbukti secara statistik berpengaruh terhadap variabel dependen

Berikut hasil pengujian hipotesis yang dilakukan dalam studi ini.

Tabel 5. Hasil Pengujian Hipotesis

\begin{tabular}{|c|c|c|c|c|c|}
\hline \multicolumn{6}{|c|}{ Coefficients $^{\mathrm{a}}$} \\
\hline \multirow[t]{3}{*}{ Model } & Unstandardize & Coefficients & Standardized & $\mathrm{t}$ & Sig. \\
\hline & & & Coefficients & & \\
\hline & B & Std. Error & Beta & & \\
\hline (Constant) & 4,984 & 1,048 & & 4,757 &, 000 \\
\hline Beban Kerja & ,413 &, 047 & ,498 & 8,857 & ,000 \\
\hline Konflik Kerja & 155 &, 051 & , 171 & 3,039 & ,003 \\
\hline
\end{tabular}

a. Dependent Variable: Stress Kerja

Sumber: Data Primer yang Diolah, 2020 


\section{Hasil Pengujian Pengaruh Beban Kerja terhadap Stress Kerja}

Pengujian ada tidaknya pengaruh beban kerja terhadap stress kerja yang menghasilkan koefisien regresi sebesar 0,498 , t hitung sebesar 8,857, dan nilai signifikansi sebesar 0,000 . Oleh karena nilai t hitung $(8,857)>$ nilai t tabel $(1,982)$ dan nilai signifikansi $(0,000)<0,05$ maka dapat disimpulkan bahwa beban kerja terbukti berpengaruh positif signifikan terhadap stress kerja.

\section{Hasil Pengujian Pengaruh Konflik Kerja terhadap Stress Kerja}

Pengujian ada tidaknya pengaruh konflik kerja terhadap stress kerja yang menghasilkan koefisien regresi sebesar 0,171, t hitung sebesar 3,039, dan nilai signifikansi sebesar 0,003 . Oleh karena nilai t hitung $(3,309)>$ nilai $t$ tabel $(1,982)$ dan nilai signifikansi $(0,003)<0,05$ maka dapat disimpulkan bahwa konflik kerja terbukti berpengaruh positif signifikan terhadap stress kerja.

Berdasarkan hasil pengujian pengaruh beban kerja dan konflik kerja terhadap stress kerja tersebut diturunkan dalam bentuk persamaan matematis berikut ini:

$$
Y=0,498 X_{1}+0,171 X_{2}
$$

Dimana :

$$
\begin{aligned}
& Y=\text { Stress kerja } \\
& X_{1}=\text { Beban kerja } \\
& X_{2}=\text { Konflik Kerja }
\end{aligned}
$$

\section{Pembahasan Pengaruh Beban Kerja terhadap Stress Kerja}

Stres merupakan suatu kondisi ketegangan yang mempengaruhi emosi, proses berpikir dan kondisi seseorang.hasilnya stress yang terlalu besar dapat mengancam kemampuan seseorang untuk menghadapi lingkungan, yang akhirnya mengganggu pelaksanaan tugas tugasnya (Handoko, 2012). Jika seseorang/karyawan mengalami stres yang terlalu besar maka akan dapat menganggu kemampuan seseorang/ karyawan tersebut untuk menghadapi lingkungannya dan pekerjaan yang akan dilakukannya.

Moorhead, Griffin, (2010), menyatakan bahwa konsekuensi final dari struktur peran yang lemah adalah kelebihan beban kerja (peran) yang terjadi ketika ekspektasi untuk peran tersebut melampaui kemampuan individual.Ketika seorang manajer memberikan beberapa tugas besar kepada seorang karyawan sekaligus sambil meningkatkan beban kerja regular orang tersebut, karywan tersebut mungkin akan mengalami beberapa kelebihan beban kerja.

Beban kerja yang bisa menyebabkan terjadinya stres kerja diantaranya adalah sistem pemberian tugas yang berlebihan, dan tekanan dan sikap pimpinan terhadap target kerja yang kurang adil dan tidak wajar. Hal-hal tersebut bisa menyebabkan terjadinya stres kerja karyawan (Fathoni, 2009).

\section{Pembahasan Pengaruh Konflik Kerja terhadap Stress Kerja}

Tujuan yang ingin dicapai oleh organisasi di atas kapal, dipengaruhi oleh adanya kerja sama antar pelaut yang harmonis dalam menyelesaikan tugas dan tanggung jawabnya. Semakin harmonis kerja sama yang dilakukan para pelaut tersebut, semakin tinggi juga kinerja yang dicapai oleh pelaut. Kenyataannya, suasana kerja diantara para pelaut tidaklah selalu tercipta dengan baik. Banyak 
faktor yang menyebabkan tidak terciptanya hubungan yang harmonis seperti ketidaksamaan prinsip, pandangan penelitian, khususnya mengenai cara untuk mencapai tujuan organisasi di atas kapal. Perbedaan tersebut mengakibatkan terjadinya konflik.

Suatu konflik merupakan hal yang wajar dalam organisasi. Konflik bukanlah menjadi suatu hal yang harus ditakutkan, tetapi merupakan suatu hal yang perlu dikelola agar dapat memberikan kontribusi bagi pencapaian tujuan organisasi. Konflik dapat menjadi energi yang kuat apabila dapat dikelola dengan baik sehingga dapat dijadikan motivasi. Jika konflik tidak dapat dikendalikan maka akan mengakibatkan stres pada pelaut yang secara tidak langsung akan berpengaruh terhadap aktivitas organisasi itu sendiri.

Pelaut yang stres (mengalami tekanan) cenderung menganggap suatu pekerjaan bukanlah sesuatu yang penting bagi mereka sehingga tidak mampu menyelesaikan pekerjaannya sesuai dengan target yang telah ditetapkan. Akan tetapi tidak semua pelaut yang mengalami tekanan pekerjaan tidak mampu menyelesaikan pekerjaannya tepat waktu dan sesuai dengan target yang telah ditetapkan.

\section{PENUTUP}

\section{Kesimpulan}

Studi empiris yang dilakukan dengan pendekatan ilmiah menunjukkan bahwa stress kerja yang dialami oleh pelaut di atas kapal dipengaruhi oleh beban kerja dan konflik kerja. Temuan ini berarti, jika stress yang dialami oleh pelaut di atas kapal meningkat maka hal ini disebabkan oleh adanya peningkatan beban kerja dan konflik kerja yang dialami pelaut di atas kapal. Stress yang terjadi pada pekerja terutama pelaut di atas kapal perlu mendapat perhatian. Oleh sebab itu diperlukan pengelolaan stress kerja agar tidak berkepanjangan dan menimbulkan efek negatif. Berdasarkan hasil studi ini untuk menekan terjadinya stress kerja, organisasi perlu memperhatikan beban kerja dan konflik kerja. Beban kerja perlu diperhatikan agar tidak melebihi kemampuan pekerja dan konflik kerja diminimalisir dengan menanamkan nilai-nilai organisasi kepada para pelaut.

\section{DAFTAR PUSTAKA}

Anuari, R., Utami, H. N., \& Prasetya, A. (2017). Pengaruh Konflik Kerja Terhadap Stres Kerja Dan Motivasi Kerja Serta Dampaknya Terhadap Komitmen Organisasional (Studi pada Karyawan PT Pelabuhan Indonesia III (Persero) Kantor Pusat). Jurnal Administrasi Bisnis, 42(1), 102-109.

Astriawati, N. (2016). Penerapan Analisis Regresi Linier Berganda Untuk Menentukan Pengaruh Pelayanan Pendidikan Terhadap Efektifitas Belajar Taruna Di Akademi Maritim Yogyakarta. Majalah Ilmiah Bahari Jogja, XIV(regresi liner), 22-37. Retrieved from http://jurnal.amy.ac.id/index.php/MIBJ/article/view/90/89

Fillhumaam, F., Nurcholis, G., \& Nurahaju, R. (2019). HUBUNGAN STRES KERJA DAN KEPRIBADIAN DENGAN BURNOUT PADA ANAK 
BUAH KAPAL (ABK) KRI "X” TNI ANGKATAN LAUT SURABAYA. Jurnal Sains Psikologi. https://doi.org/10.17977/um023v8i22019p199

Han, C., \& Ketut Netra, I. (2014). PENGARUH KONFLIK TERHADAP STRES KERJA DAN KEPUASAN KERJA KARYAWAN. E-Jurnal Manajemen Universitas Udayana.

Hatmawan, A. A. (2015). PENGARUH KONFLIK KERJA, BEBAN KERJA SERTA LINGKUNGAN KERJA TERHADAP STRES PEGAWAI PT. PLN (Persero) AREA MADIUN RAYON MAGETAN. Assets: Jurnal Akuntansi Dan Pendidikan. https://doi.org/10.25273/jap.v4i1.678

Kusuma Aster Andriani. (2014). Pengaruh Beban Kerja Terhadap Stres Kerja Dan Dampaknya Terhadap Kinerja Karyawan. Jurnal Ilmu Manajemen (JIM).

Presiden Republik Indonesia. Peraturan Pemerintah Republik Indonesia Nomor 7 Tahun 2000 Tentang Kepelautan. , (2000).

Purbaningrat, Y. P. M., \& Ketut, S. I. B. (2015). PENGARUH BEBAN KERJA TERHADAP KEPUASAN KERJA DENGAN STRES KERJA SEBAGAI VARIABEL MEDIASI. E-Jurnal Manajemen Universitas Udayana.

Rizky, D., \& Afrianty, T. W. (2018). Pengaruh Beban Kerja Terhadap Stres Kerja Dengan Work Life Balance Sebagai Variabel Intervening (Studi Pada Dinas Sosial Provinsi Jawa Timur Surabaya). Jurnal Administrasi Bisnis (JAB).

Robbins, S. P., Judge, T. A., Odendaal, A., \& Roodt, G. (2016). Organisational behaviour: Global and Southern African Perspectives. In Pearson South Africa (Pty) Ltd.

Zulmaidarleni, Z., Sarianti, R., \& Fitria, Y. (2019). PENGARUH BEBAN KERJA DAN LINGKUNGAN KERJA FISIK TERHADAP STRES KERJA PADA PEGAWAI KANTOR KECAMATAN PADANG TIMUR. Jurnal Ecogen. https://doi.org/10.24036/jmpe.v2i1.6133 